\section{Even the musical was better than this}

\author{
The Klone and I \\ by Danielle Steel
}

Delacorte Press, \$17.95, ISBN 0-385-32392-1, 1999

Reviewed by Alan Colman

PPL Therapeutics, Roslin, Edinburgh EH 25 9PP, UK

As someone who was weaned on a diet of Alberts et al., I was hopeful that Danielle Steel's The Klone and I might have something to teach me about a higher form of conjugation. Unfortunately, not only is the sex bad, the book fails to reflect a basic understanding of the science its title trades on. This is not a book about a biological clone, but rather, a cyborg.

The storyline is wellworn. Living near New York, middle-aged, happily married Stephanie, with young children, takes her husband for granted and neglects her

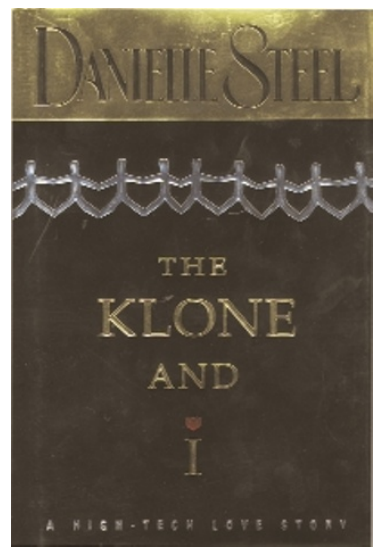
wife's trust fund, finds a younger, shapelier and richer woman. Divorce ensues. Enter right, Peter Baker, a suave, lithe, older man who is intelligent, witty, athletic, wealthy, sensitive, warm, handsome and considerate. Have I missed an adjective? Yes, I have: he is child-loving, too. Peter proceeds to woo our heroine and succeeds in bedding her.

Peter is the owner and chairman of a bionics (biology and electronics) company in Silicon Valley. He often returns to California for business. But while the cat's appearance. The ne'er-do-well husband, away, the klones play. Enter left, Paul Roger, a financial failure reliant on his Klone, an amalgam of advanced fabrics and electrical wizardry, and Peter's alter ego. They are physically identical, but behaviourally, the complete opposite: day-glo satin and rhinestones instead of navy jacket and pressed khaki. And what a lover! Each time Peter returns, the Klone vanishes. The pattern of the book is set. Which of the two does she prefer?

Popular novels, by definition, play to the gallery (Steele has sold over 370 million books). But those written in the wake of highly publicized scientific advances sometimes have, buried within the chaff of human intrigue and romantic angst, insights to offer. I looked hard for these in Steele's latest novel and found none.

It is now possible to clone a person from an adult cell donor. One of the most common misconceptions about human reproductive cloning is that clones will be psychologically and behaviorally identical to their human templates. Even though Steele uses the term 'klone' misleadingly, she does ascribe to Paul, Peter's klone, a unique personality. One suspects, however, this may have been the product of mere accident. By contrast, The Boys from Brazil is inaccurate on the genetics versus personality point, but at least we can thank its author, Ira Levin, for being wrong in an interesting way.

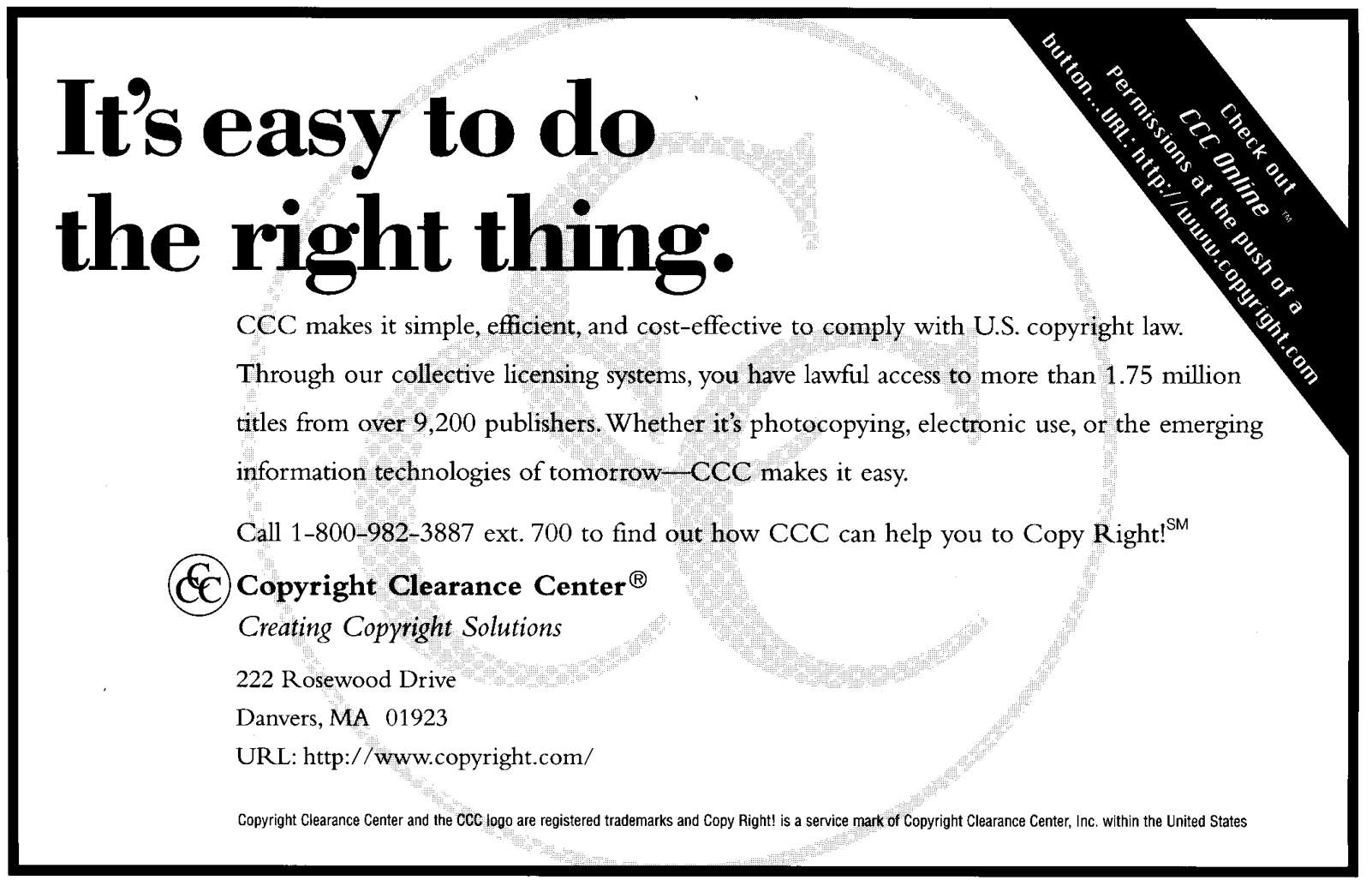

